\title{
STRATEGI ADAPTASI PEDAGANG ANGKRINGAN DALAM MEMPERTAHANKAN EKSISTENSI HIDUP STUDI DI KAWASAN JL. K.H. ALI MAKSUM KRAPYAK YOGYAKARTA (Perbandingan Antara Angkringan Tradisional Versus Angkringan Modern)
}

\author{
Kurniati \\ Perbankan STIA Alma Ata Yogyakarta \\ Email:kurniati.khalil.kk@gmail.com
}

\begin{abstract}
The theme of this research on adaptation strategies angkringan traders to exist in the face of the dynamics of life in the surrounding area of Jl. K.H. Ali Maksum Krapyak, Bantul, Yogyakarta. Researchers want to know how the strategy or the efforts made by angkringan traders in order to maintain his existence and how social capital, which in turn play a role in these efforts. The strategy can be formulated as an effort to maintain his existence as a angkringan's trader around Jl. K.H. Ali Maksum Krapyak, Bantul, Yogyakarta.

The method used in this research using descriptive qualitative method. In this study, there are two classifications of traders who hung (trade) around the area of Jl. K.H. Ali Maksum Krapyak, Bantul, Yogyakarta, which is used as one of the objects of informants, namely traders patterned angkringan traditional and modern. Through the narrative they can know how the efforts and strategies undertaken to maintain his existence in the face of the dynamics of life in the surrounding area of Jl. K.H. Ali Maksum Krapyak, Bantul, Yogyakarta.

The strategy is one of them is to increase infrastructure facilities in Angkringan, such as a more representative (wider), Television, snacks are varied, not only the main menu as in angkringan others. In this study found the factors underlying the existence of traders angkringan and efforts are being made to defend themselves in the face of the local economy.
\end{abstract}

Keywords: Existence, Strategy adaptation, Angkringan Traders, Krapyak Bantul.

\section{PENDAHULUAN}

\section{Latar Belakang Masalah}

Salah satu usaha yang berkibar meski diterpa badai krisis, baik krisis yang menyediakan makanan beserta minuman tertentu dan harganya yang sangat terjangkau. Seperti yang dilakukan pedagang angkringan di sekitar kawasan Jln. Ali Maksum Krapyak Bantul Yogyakarta yang sudah cukup lama mencari nafkah dengan usaha angkringan. Menurut pemamparan mereka 
bahan baku untuk membuat berbagai makanan dan minuman yang akan dijajakan mudah didapat, seperti beras. Gula, jahe, sayuran, dan lain lain.

Setelah kami amati, peminat jajanan dari angkringannya cukup banyak, terutama santri, mahasiswa yang indekos di sekitar Krapyak, bahkan masyarakat setempat banyak juga yang menikmati jajanan dari angkringan. Selain harga yang ditawarkan sangat terjangkau bagi kalangan mahasiswa yang banyak berasal dari luar jawa, ataupun orang-orang sekitar. Angkringan dapat menjadi alternative jika sedang bersantai atau makan siang terutama bagi mahasiswa dan santri. Modal awal yang tidak terlalu banyak, dan bahan baku yang mudah didapat, menjadi pilihan yang tepat untuk menekuni usaha ini. Dari situ keuntungan yang didapat juga cukup banyak. Di tambah lagi hampir keseluruhan makanan yang disajikan merupakan titipan dari suplier, sehingga dapat meminimalisir risiko kerugian karena setiap dagangan yang tidak habis akan kembali kepada suplier. Dari itulah usaha ini bisa juga menjadi alternatif untuk bangkit dari krisis global yang sedang melanda.

Perilaku konsumen pun bermacam-macam di sana. Ada yang hanya membeli untuk dibawa pulang, ada pula yang membeli, makan sebentar lalu pulang, namun yang paling sering ditemui adalah membeli, ngobrol, membeli lagi, dan ngobrol lagi di warung angkringan bersama rekan maupun "rekan-rekan" baru yang ditemui dan di kenal di sana. Otomatis, di angkringan tidak ada pembedaan strata sosial, agama maupun ras. Mereka semua sama di keremangan lampu senthir, sebagai sosok anak manusia yang makan dan minum dari tangan penjual yang sama.

Di dalam dunia angkringan tidak di kenal kelas dan golongan. Semua yang hadir adalah sedulur, semua saudara. Mahasiswa, tukang becak, kusir andhong, buruh gendhong, para guru dan dosen, seniman, tukang ngamen, bahkan copet dan jembret sah-sah saja datang berkumpul. Dunia angkringan tidak mengenal perbedaan usia, tua-muda, besar-kecil, kaya-miskin, pintarbodoh, ndeso-kota menjadi ajur ajer dalam kehangatan persaudaraan.

Angkringan adalah dunia dengan sejuta rasa egalitarianisme yang universal. Semua yang berkumpul adalah manusia. Manusia dengan kepolosan jiwa yang senantiasa merindukan persamaan, duduk sama rendah berdiri sama tinggi. Manusia semakin merasa tersisih dan kehilangan jiwa sejatinya. Dan angkringanlah salah satu wujud pencarian jiwa sejati manusia tersebut.

Menilik animo masyarakat terhadap usaha angkringan yang begitu tinggi, maka semakin banyak bermunculan angkringan-angkringan baru yang ingin mengundi peruntungan pada jenis usaha tersebut. Bahkan para penyandang dana, tidak segan-segan menginvestasikan dananya pada usaha angkringan, dengan cara bagi hasil dengan pedagang angkringannya. Dengan demikian hal ini menjadi tantangan bagi para pedagang angkringan untuk menyusun strategi baru, dalam mempertahankan eksistensi usahanya tersebut.

Setiap manusia senantiasa berusaha untuk melangsungkan dan menjaga kelangsungan hidupnya dengan baik. Dalam kerangka ini maka manusia senantiasa berusaha beradaptasi dengan lingkungan, baik fisik, sosial, maupun ekonomi yang melingkupinya itu. Begitu pula dengan penjual jajanan angkringan di sekitar kawasan jln. K.H. Ali Maksum Krapyak, kelurahan Panggung Harjo, kecamatan Sewon, Kabupaten Bantul Yogyakarta. Dalam situasi krisis seperti dewasa ini, maka mereka pun dituntut pula untuk beradaptasi dengan berbagai persoalan yang muncul terutama yang

\section{Kurniati}

JURNAL EKONOMI SYARIAH INDONESIA, Volume V, No.2 Desember 2015 
terkait dengan imbas krisis ekonomi terhadap kelangsungan hidup mereka sekeluarga.

Pengertian adapatasi menurut Parsudi Suparlan (1984). Adalah suatu proses yang dilakukan manusia untuk mengatasi berbagai kendala yang ada dalam linkungan sosial, budaya, ekonomi, dan alam. ${ }^{1}$ Untuk memenuhi syarat-syarat dasar guna kelangsungan hidup. Pemenuhan syarat-syarat dasar itu mencakup kebutuhan jasmaniah atau biologis (misalnya makan, minum, tempat berlindung, dan tubuh yang sehat), syarat sosial (misalnya membutuhkan bantuan, dan bergaul dengan orang lain), dan syarat kejiwaan (misalnya rasa aman, tentram, dan ingin dicintai).

Dalam Kamus bahasa Indonesia adaptasi sering diartikan sebagai penyesuaian diri. Kata menyesuaikan diri menunjukkan pengertian adanya sesuatu yang disesuaikan terhadap sesuatu yang lain. Dalam menyesuaikan diri menunjukkan pengertian adanya sesuatu yang disesuaikan terhadap sesuatu yang lain. Dalam menyesuaikan diri dengan lingkungnannya, dan untuk itulah manusia menjalankan strategi adaptasi.

Menurut J.W. Bennett (1972), strategi beradaptasi (adaptive strategies) tidak lain adalah pola-pola yang dibentuk oleh berbaagai penyesuaian yang direncanakan oleh manusia untuk mendapatkan dan menggunakan sumber daya dan untuk memecahkan masalah yang langsung mereka hadapi (Ahimsaputra: 1980). Kegiatan menggunakan atau mendapatkan sumberdaya tersebut tujuannya adalah untuk memenuhi syarat minimal agar tetap hidup. Usaha tersebut dikatakan sesuai apabila melalui usaha ini daapt tercapai suatu tujuan yang diinginkan. Dengan demikian strategi adaptasi adalah polapola yang dibentuk oleh berbagai usaha yang direncanakan manusia, untuk memenuhi syarat minimal yang dibutuhkannya dan untuk memecahakan masalah-masalah yang langsung mereka hadapi (Ahimsa putra: 1980).

Dalam kasus penjual angkringan, terdapat cirri khas dan keunikan sendiri berkait berkait dengan pola adaptasinya. Sistem perdagangan yang belum lama muncul yang kemudian berkembang begitu pesat tentu mempunyai proses adaptasi yang di dalamnya muncul aturan-aturan dan nilai-nilai serta cara kerja yang begitu mendadak. Dengan demikian terjadi penyesuaian yang sangat cepat bagi pedagang-pedagang yang ada untuk tetap dapat hidup dalam komunitas pedagang angkringan tersebut. Para pedagang harus berusaha menjalankan teknik-teknik dan strategi yang digunakan untuk berhubungan dengan lingkungan fisik, sosial, budaya yang ada, untuk mencapai atau meningkatakan tujuan yang diinginkan, yaitu peningkatan kehidupan ekonominya. Para pedagang juga harus menjalankan norma yang berlkaku yang berisi pedoman-pedoman untuk memberikan respon terhadap pelanggaran norma, yang dilakukan oleh orang lain. Semua usaha tersebut berpusat dalam tujuan yang sama yang mereka lakukan yaitu peningkatan kehidupan ekonomi lewat berdagang angkringan.

\section{Strategi Adaptasi}

${ }^{1}$ Yang dimaksud dengan lingkungan sosial adalah suatu bagian dari lingkungan hidup yang terdiri atas hubungan individu dan kelompok dan pola-pola organisasi serta segala aspek yang ada dalam masyarakat yang lebih luas. (Suparlan, 1984). Lingkungan budaya berhubungan dengan nilai-nilai, norma-norma, peraturan-peraturan, dan adat-istiadat. Lingkungan ekonomi berhubungan hal-hal atau kegiatan manusia dalam mencari nafkah. Lingkungan alam berhubungna dengan keadaan fisik alam suatu tempat, misalnya di kota banyak pabrik, dan kendaraan, seertra jalan sudah diaspal. Di desa banyak sawah, jalan-jalan belum diaspal, kendaraan, dan bangunan sedikit. 
Proses adaptasi tersebut menjadi lebih ringan dilakukan oleh para pedagang, karena kehidupan kelompok yang dilakukan serta ikatan primordial yang masih kuat. Hubungan yang terjalin antar pedagang, antar pedagang dan pelanggan terjalin dengan baik, dan antar pedagang tidak terjadi persaingan yang tidak adil.

\section{Pokok Permasalahan}

Berdasarkan latar belakang masalah yang telah dipaparkan di atas, maka dapat dirumuskan pokok permasalahan sebagai berikut: 1. Bagaimana strategi adaptasi yang dilakukan Pedagang angkringan di sekitar Kawasan Jln. K.H. Ali Maksum Krapayak Bantul Yogyakarta dalam mempertahankan hidupnya. 2. Bagaimana hal tersebut diatas dipandang dalam perspektif Etika Bisnis slam.

\section{Tujuan Penelitian}

\section{Tujuan Penelitian}

Penelitian ini bertujuan untuk menjelaskan strategi adapatasi yang dilakukan Pedagang angkringan di sekitar Kawasan Jln. K.H. Ali Maksum Krapayak Bnatul Yogyakarta dalam mempertahankan eksistensi hidupnya.

Untuk menjelaskan dari perspektif Etika Bisnis Islam tentang strategi adapatasi yang dilakuakn Pedagang angkringan di sekitar Kawasan Jln. K.H. Ali Maksum Krapayak Bnatul Yogyakarta dalam mempertahankan eksistensi hidupnya.

\section{Kegunaan Penelitian.}

SecaraTeoritis

Secara teoritis penelitian ini dapat digunakan sebagai landasan penelitian yang selanjutnya serta menambah wawasan mengenai strategi adapatasi yang dilakukann Pedagang angkringan di sekitar Kawasan Jln. K.H. Ali Maksum Krapayak Bantul Yogyakarta dalam mempertahankan eksistensi hidupnya dan memperkaya khasanah keilmuan, terutama dalam bidang sosial.

\section{Secara Praktis}

\section{Bagi Penulis}

Penelitian ini dapat digunakan sebagai sarana berpikir ilmiah untuk dapat memahami secara kritis mengenai kehidupan Pedagang angkringan di sekitar Kawasan Jln. K.H. Ali Maksum Krapayak Bantul Yogyakarta, sekaligus dapat menerapkan ilmu yang diperoleh dari kegiatan perkuliahan.

\section{Bagi masyarakat di Krapyak}

Penelitian ini sebagai salah satu wacana untuk meningkatkan kepedulian sosial terhadap pedagang angkringan, terutama Pedagang angkringan di sekitar Kawasan Jln. K.H. Ali Maksum Krapayak Bantul Yogyakarta.

\section{Bagi Pemerintah Daerah Istimewa Yogyakarta}

Sebagai wahana peningkatan kesejahteraan masyarakat Yogyakarta pada umumnya, terutama masyarakat pra sejahtera.

Kurniati

JURNAL EKONOMI SYARIAH INDONESIA, Volume V, No.2 Desember 2015 


\section{Kerangka Teori}

\section{Pengertian Eksistensi.}

Menurut Kamus Besar Bahasa Indonesia kata eksistensi termasuk ke dalam kelompok kata benda yang berarti hal berada, keberadaan (Purwodarminto. 2002: 288). Sedangkan eksistensi sendiri dibatasi sebagai keberadaan suatu hal. Jika dikaitkan dengan kehidupan manusia maka setiap manusia berdasarkan nalurinya baik individual ataupun kelompok menginginkan akan pengakuan eksistensi dirinya dalam kehidupan masyarakat. Berbagai cara manusia lakukan untuk mempertahankan eksistensi dirinya.

\section{Strategi Adaptasi}

Dalam Kamus bahasa Indonesia adaptasi sering diartikan sebagai penyesuaian diri. Kata menyesuaikan diri menunjukkan pengertian adanya sesuatu yang disesuaikan terhadap sesuatu yang lain. Dalam menyesuaikan diri menunjukkan pengertian adanya sesuatu yang disesuaikan terhadap sesuatu yang lain. Dalam menyesuaikan diri dengan lingkungnannya, dan untuk itulah manusia menjalankan strategi adaptasi.

Menurut J.W. Bennett (1972), strategi beradaptasi (adaptive strategies) tidak lain adalah pola-pola yang dibentuk oleh berbagai penyesuaian yang direncanakan oleh manusia untuk mendapatkan dan menggunakan sumber daya dan untuk memecahkan masalah yang langsung mereka hadapi (Ahimsaputra: 1980). Kegiatan menggunakan atau mendapatkan sumberdaya tersebut tujuannya adalah untuk memenuhi syarat minimal agar tetap hidup. Usaha tersebut dikatakan sesuai apabila melalui usaha ini dapat tercapai suatu tujuan yang diinginkan. Dengan demikian strategi adaptasi adalah polapola yang dibentuk oleh berbagai usaha yang direncanakan manusia, untuk memenuhi syarat minimal yang dibutuhkannya dan untuk memecahakan masalah-masalah yang langsung mereka hadapi (Ahimsa putra: 1980).

Lebih lanjut Ahimsa mengatakan, kata menyesuaikan diri mengandung pengertian adanya sesuatu yang disesuaikan terhadap sesuatu yang lain. Menurut Malinowski seperti dikutip oleh Ahimsa Putra (1980) manusia membutuhkan tiga syarat minimal yang harus dipenuhi agar tetap dapat bertahan hidup, yaitu syarat biologi, syarat kejiwaan dan syarat sosial. Dengan demikian proses adaptasi dapat diartikan sebagai perubahan dalam pola kegiatan atau tingkah laku untuk tetap dapat memenuhi syarat minimal agar bisa bertahan hidup dalam suatu lingkungan.

Bennett (1972) sebagimana dikutip Ahimsa membagi strategi adaptasi menjadi tiga macam; yaitu pertama, perilaku adaptasi, kedua, proses adaptasi, dan ketiga. siasat adaptasi, Pada dasarnya adaptasi dapat didefinisikan sebagai perilaku yang berkenaan dengan pencapaian tujuan yang diinginkan dengan mengatasi berbagai kendala yang sulit. Menurut Ahimsa, paradigma ini juga berkaitan dengan teori pattern for dan pattern of, pola bagi dan pola dari, pola pola di sini adalah pola pola perilaku atau tindakan (Ahimsa Putra, 2003:12)

\section{Strategi Adaptasi}

\section{Angkringan}

Keberadaan angkringan tidak jelas kapan dimulainya. Angkringan merupakan turunan kata dari angkring, nangkring, ngangkring. Ngangkring pada awalnya bermakna posisi seekor ayam atau unggas lain yang berdiri maupun ndhodhok, di sebuah tempat pijakan dengan ketinggian tertentu dari 
permukaan tanah. Gerobak dengan bangku sebagai tempat duduk pembeli, dan posisi kaki yang seringkali jegang, tumpang tali atau bahkan naik ke atas bangku dipandang mirip perilaku ngangkringangkringan, tempat ngangkring. Yang merupakan ciri manusia Jawa. Maka dari situlah lahir istilah angkringan.

Setelah mengamati beberapa angkringan di jogjakarta, secara garis besar Angkringan adalah tempat berjualan berbagai macam makanan yang berwujud seperti sebuah gerobak dorong yang berisi penuh makanan dan jajan, beroperasi di sore, malam dan dinihari dan menggunakan penerangan lampu senthir (kebanyakan) serta temaramnya lampu-lampu mercury jalanan Jogja.

Makanan khas menu angkringan diantaranya adalah sego kucing, sate usus, sate endhok gemak, tahu dan tempe bacem, kikil sunduk, pisang goreng, bakwan, tahu susur, cucur, apem, tawonan dan segala macam makanan khas Jawa yang lain. Adapun minuman yang menemani obrolan seringkali disuguhkanlah wedang jahe anget, teh jahe, teh panas legi kenthel, kopi murni, hingga kopi susu dengan gula batu khasnya.

Soal makan dan jual beli nampaknya bukanlah hal utama yang seringkali membuat orang datang ke angkringan. Yang sering terjadi adalah kelamaan ngobrol ngalor ngidul tanpa juntrungan yang jelas, sambil dulat-dulit nyamil makanan. Makan Rp.4.000-5.000 bisa setengah malaman sendiri. Bagi si penjualpun nampaknya omset penjualan dan target pencapaian profit bukanlah segala-galanya, karena bagi mereka ono dino ono upo(ada hari ada rejeki). Ngraketke paseduluran, menyambung persaudaraan itu hakikat nilai yang ingin diraih.

\section{Etika Bisnis Islam}

Menurut Jalaluddin Rahmat, sebagaimana dikutip oleh Abuddin Nata, Islam ternyata agama yang menekankan aspek kehidupan sosial (muamalah) lebih besar dari pada aspek ritual (ibadah dalam arti khusus). (Abudin Nata; 1999. 89) Muamalah menempati ruang lingkup yang luas sekali sedangkan ibadah ruangnya cukup terbatas. Namun jika dilihat dari nas yang mengaturnya, lebih banyak nas yang mengatur tentang ibadah dari pada nas yang mengatur tentang muamalah. Hukum ibadah aturannya lebih jelas, sedangkan hukum muamalah sedikit yang dapat dijangkau oleh nas yang jelas. (Amir. S. 2002. 133-134). Dalam muamalah, manusia diberi kebebasan untuk menetapkan ketentuan yang tidak terdapat dalam nas asalkan tidak bertentangan dengan aturan pokok Dalam hal ini sebagian besar ahli fiqh menetapkan kaidah:

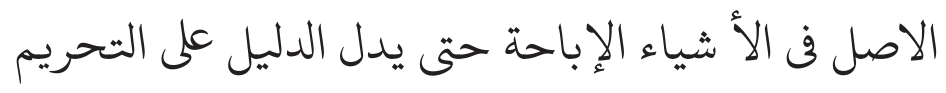

"hukum asal (dasar) segala sesuatu itu boleh (mubah) sampai terdapat dalil yang mengharamkannya. (Asmuni Abdurrahman. 1976. 41.).

Keharusan menyesuaikan hasil pemahaman ayat al-Quran yang berkenaan dengan hukum muamalah dengan perkembangan zaman perlu dilakukan dengan cara inilah maka kehadiran al-Qur'an secara fungsional dapat dirasakan oleh masyarakat.

Ahmad Azhar Basyir merumuskan prinsip-prinsip hukum muamalah sebagai berikut: 1 . Pada dasarnya segala bentuk muamalah adalah mubah, kecuali yang ditentukan lain oleh al- Quran dan sunnah Rasul, 2. Muamalah

\section{Kurniati}

184

JURNAL EKONOMI SYARIAH INDONESIA, Volume V, No.2 Desember 2015 
dilakukan atas dasar sukarela, tanpa mengandung unsur-unsur paksaan. 3. Muamalah dilakukan atas dasar pertimbangan mendatangkan manfaat dan menghindarkan madharat dalam hidup masyarakat. 4. Muamalah dilaksanakan dengan memelihara nilai keadilan menghindari penganiayaan, menghindari unsur-unsur pengambilan kesempatan dalam kesempitan. (Asmuni Abdurrahman. (Ahmad Azhar Basyir, 2000. 15-16).

Bisnis dan perdagangan termasuk dalam kegiatan manusia yang terpenting, dan manusia adalah makhluk yang memerlukan teman dan kelompok. Bisnis dan perdagangan diperlukan karena tidak ada seorangpun yang dapat hidup dengan sempurna, mampu menyediakan segala keperluan dan tuntutan hidupnya sendiri tanpa melibatkan orang lain. Oleh karena itu manusia saling memerlukan, bekerjasama dan saling tolong menolong.

Islam mendorong ummatnya berusaha mencari rezeki supaya kehidupan mereka menjadi baik dan menyenangkan. Allah SWT menjadikan langit, bumi, laut dan apa saja untuk kepentingan dan manfaat manusia. Manusia hendaklah mencari rezeki yang halal. Firman Allah Swt, yang berbunyi sebagai berikut:

Firman Allah dalam surah An-Naba(78) : 10-11 :

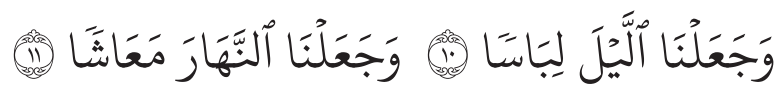

Dan Kami jadikan malam sebagai pakaian. Dan Kami jadikan siang untuk penghidupan.

Dalam ayat itu Allah mengajarkan keseimbangan antara mencari rezeki untuk kehidupan dan beristirahat (leisure). Malam hari untuk beristirahat dan mengumpulkan tenaga dan siang hari bekerja mencurahkan tenaga, berbisnis berdagang untuk mencari rezeki.

Dalam beberapa hadis Rasulullah SAW memberikan dorongan kepada umatnya untuk mencari rezeki dengan berusaha dan berdagang. Rasulullah sendiri adalah contoh seorang pedagang yang sukses. Ketika masih kecil beliau telah menemani pamannya Abu Thalib berdagang keSyam, bahkan beliau sendiri menjalankan bisnis milik Siti Khadijah keSyam dan kembali dengan keuntungan yang besar. Ini adalah bukti kemampuan, kepercayaan dan amanah beliau sebagai pedagang. Para sahabat Rasul juga banyak yang menjadi pengusaha dan bussinessman yang sukses. Diantaranya adalah Abu Bakar, Umar bin Khattab, Ustman bin Affan, Abdurrahman bin Auf, dan lain-lain. Sebagaimana keterangan dalam sabda Rasulullah SAW, yang artinya sebagai berikut:

"Pedagang yang amanah dan benar akan ada bersama dengan para syuhada di hari qiyamat nanti" (HR. Ibnu Majah dan al-Hakim).

"Tidak ada makanan yang lebih baik yang dimakan oleh seseorang daripada yang dihasilkan oleh tangannya sendiri". (HR. Bukhari)

Walaupun Islam mendorong ummatnya untuk berdagang, dan bahkan merupakan fardhu al-Kifayah, bukan berarti dapat dilakukan sesuka dan sekehendak manusia, seperti lepas kendali. Adab dan etika bisnis dalam Islam harus dihormati dan dipatuhi jika para pedagang dan pebisnis ingin termasuk dalam golongan para Nabi, Syuhada dan Shiddiqien. Keberhasilan masuk dalam kategori itu merupakan keberhasilan yang terbesar bagi seorang muslim.

\section{Strategi Adaptasi}

185
Ummat Islam dalam kiprahnya mencari kekayaan dan menjalankan usahanya hendaklah menjadikan Islam sebagai dasarnya dan keridlaan Allah sebagai tujuan akhir dan utama. Mencari keuntungan dalam melakukan perdagangan merupakan salah satu tujuan, tetapi jangan sampai mengalahkan 
tujuan utama. Dalam pandangan Islam bisnis merupakan sarana untuk beribadah kepada Allah dan merupakah fardlu kifayah, oleh karena itu bisnis dan perdagangan tidak boleh lepas dari peran Syari'ah Islamiyah.

Orang yang dikuasai oleh harta dan bisnisnya sehingga mengabaikan kewajiban terhadap Allah SWT adalah orang-orang yang iman dan akhlaqnya tipis, dan ini bertentangan dengan Syari' ah Islamiyah. Allah pernah menegur beberapa orang Islam zaman Rasulullah SAW. Pasalnya adalah ketika Rasulullah sedang menyampaikan khutbah Jum'at, mereka mendengar kedatangan kafilah yang membawa dagangan dari Syam. Kebetulan pada waktu itu kota Madinah sedang mengalami kekurangan makanan, sehingga mereka tidak sabar lagi untuk segera mendatangi kafilah tersebut, maka turunlah firman Allah Swt yang berbunyi sebagai berikut:

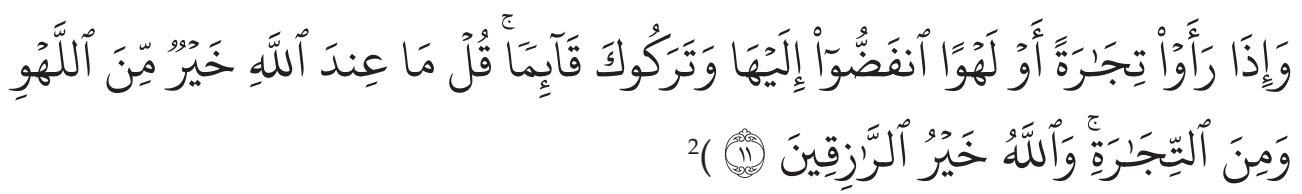

Allah Swt mencela perbuatan mereka yang mengabaikan kewajiban agama karena urusan bisnis. Adab dan etika bisnis hendaklah dijaga dan kewajiban terhadap Allah tidak boleh diabaikan. Setelah kewajiban ini ditunaikan Allah mendorong orang yang beriman untuk melanjutkan kegiatan bisnisnya, sambil terus mengingat Allah dalam setiap detak jantung dan denyut nadi.

Demikian beberapa batasan-batasan etika yang diberikan oleh Islam dalam kita menjalankan kegiatan ekonomi dan bisnis. Dengan batasan-batasan tersebut kegiatan ekonomi dan bisnis kita akan memiliki nilai ibadah, hal ini sesuai dengan misi diciptakannya manusia.

Aktivitas Bisnis yang Terlarang dalam Syariah

Menghindari transaksi bisnis yang diharamkan agama Islam. Seorang muslim harus komitmen dalam berinteraksi dengan hal-hal yang dihalalkan oleh Allah SWT. Seorang pengusaha muslim tidak boleh melakukan kegiatan bisnis dalam hal-hal yang diharamkan oleh syariah. Dan seorang pengusaha muslim dituntut untuk selalu melakukan usaha yang mendatangkan kebaikan dan masyarakat. Bisnis, makanan tak halal atau mengandung bahan tak halal, minuman keras, narkoba, pelacuran atau semua yang berhubungan dengan dunia gemerlap seperti night club discotic cafe tempat bercampurnya lakilaki dan wanita disertai lagu-lagu yang menghentak, suguhan minuman dan makanan tak halal dan lain-lain (QS: Al-A'raf;32. QS: Al Maidah;100) adalah kegiatan bisnis yang diharamkan.

Menghindari cara memperoleh dan menggunakan harta secara tidak halal. Praktik riba yang menyengsarakan agar dihindari, Islam melarang riba dengan ancaman berat (QS: Al Baqarah;275-279), sementara transaksi spekulatif amat erat kaitannya dengan bisnis yang tidak transparan seperti perjudian, penipuan, melanggar amanah sehingga besar kemungkinan akan merugikan. Penimbunan harta agar mematikan fungsinya untuk dinikmati oleh orang lain serta mempersempit ruang usaha dan aktivitas ekonomi adalah perbuatan tercela dan mendapat ganjaran yang amat berat (QS:At Taubah; 34 - 35). Berlebihan dan menghamburkan uang untuk tujuan yang tidak bermanfaat dan berfoya-foya kesemuanya merupakan perbuatan yang

\section{Kurniati}

JURNAL EKONOMI SYARIAH INDONESIA, Volume V, No.2 Desember 2015 
melampaui batas. Kesemua sifat tersebut dilarang karena merupakan sifat yang tidak bijaksana dalam penggunaan harta dan bertentangan dengan perintah Allah (QS: Al a'raf;31).

Persaingan yang tidak fair sangat dicela oleh Allah sebagaimana disebutkan dalam Al-Quran surat Al Baqarah: 188: Janganlah kamu memakan sebagian harta sebagian kamu dengan cara yang batil_. Monopoli juga termasuk persaingan yang tidak fair Rasulullah mencela perbuatan tersebut : Barangsiapa yang melakukan monopoli maka dia telah bersalah_, Seorang tengkulak itu diberi rezeki oleh Allah adapun sesorang yang melakukan monopoli itu dilaknat_. Monopoli dilakukan agar memperoleh penguasaan pasar dengan mencegah pelaku lain untuk menyainginya dengan berbagai cara, seringkali dengan cara-cara yang tidak terpuji tujuannya adalah untuk memahalkan harga agar pengusaha tersebut mendapat keuntungan yang sangat besar. Rasulullah bersabda: Seseorang yang sengaja melakukan sesuatu untuk memahalkan harga, niscaya Allah akan menjanjikan kepada singgasana yang terbuat dari api neraka kelak di hari kiamat.

Pemalsuan dan penipuan, Islam sangat melarang memalsu dan menipu karena dapat menyebabkan kerugian, kezaliman, serta dapat menimbulkan permusuhan dan percekcokan. Allah berfirman dalam QS:Al-Isra;35: dan sempurnakanlah takaran ketika kamu menakar dan timbanglah dengan neraca yang benar. Nabi bersabda apabila kamu menjual maka jangan menipu orang dengan kata-kata manis. Dalam bisnis modern paling tidak kita menyaksikan cara-cara tidak terpuji yang dilakukan sebagian pebisnis dalam melakukan penawaran produknya, yang dilarang dalam ajaran Islam. Berbagai bentuk penawaran (promosi) yang dilarang tersebut dapat dikelompokkan sebagai berikut: Penawaran dan pengakuan (testimoni) fiktif, bentuk penawaran yang dilakukan oleh penjual seolah barang dagangannya ditawar banyak pembeli, atau seorang artis yang memberikan testimoni keunggulan suatu produk padahal ia sendiri tidak mengkonsumsinya. Iklan yang tidak sesuai dengan kenyataan, berbagai iklan yang sering kita saksikan di media televisi, atau dipajang di media cetak, media indoor maupun outdoor, atau kita dengarkan lewat radio seringkali memberikan keterangan palsu. Eksploitasi wanita, produk-produk seperti, kosmetika, perawatan tubuh, maupun produk lainnya seringkali melakukan eksploitasi tubuh wanita agar iklannya dianggap menarik. Atau dalam suatu pameran banyak perusahaan yang menggunakan wanita berpakaian minim menjadi penjaga stand pameran produk mereka dan menugaskan wanita tersebut merayu pembeli agar melakukan pembelian terhadap produk mereka.

\section{Metode Penelitian.}

Agar penelitian ini dapat dilakukan dengan baik dan mendapatkan hasil yang akurat serta bisa dipertanggungjawabkan secara moral dan intelektual, maka diperlukan suatu metode penelitian. ${ }^{3}$ Adapun metode penelitian yang digunakan dalam melakukan penelitian ini sebagai berikut:

\section{Strategi Adaptasi}

3Metode (yunani: methodos) adalah cara atau jalan, sehubungan dengan upaya ilmiah, maka metode menyangkut cara kerja, yaitu cara kerja untuk dapat memahami objek yang menjadi sasaran ilmu yang bersangkutan. Baca juga, (Fuad Hasan dan Koentjaraningrat. 1986. 7), Sedangkan Penelitian (Inggris: research) berarti pencarian kembali. Yakni kegiatan pengumpulan, pengolahan, analisis, dan penyajian data yang dilakukan secara sistematis dan objektif untuk memecahkan suatu persoalan atau menguji suatu hipotesis untuk mengembangkan prinsip-prinsip umum. 


\section{Jenis Penelitian}

Penelitian ini termasuk jenis penelitian lapangan (field research) yaitu penelitian dengan menggunakan penelitian langsung dengan strategi adapatasi yang dilakuakn Pedagang angkringan di sekitar Kawasan Jln. K.H. Ali Maksum Krapayak Bnatul Yogyakarta sebagai sumber data primer, sedangkan data skunder adalah buku-buku yang secara langsung memiliki relevansi terhadap objek penelitian ini, termasuk data aktual yang diperoleh dari karya ilmiah yang diakui kevalidannya secara akademis.

\section{Sifat Penelitian}

Penelitian ini bersifat deskriptik-analitik, ${ }^{4}$ yakni berusaha menjelaskan dan memaparkan strategi adapatasi yang dilakuakn Pedagang angkringan di sekitar Kawasan Jln. K.H. Ali Maksum Krapayak Bnatul Yogyakarta dalam mempertahankan eksistensi hidupnya dan meninjaunya dari perspektif Etika Bisnis Islam.

\section{Pendekatan Penelitian.}

Pendekatan yang dipakai dalam penulisan skripsi ini adalah :

Pendekatan Normatif. ${ }^{5}$ yakni pendekatan terhadap masalah yang diteliti dengan didasarkan pada prinsip-prinsip muamalah juga kaidah-kaidah fiqhiyah yang berhubungan dengan permasalahan yang ada. Dalam hal ini penyusun menggunakan tolak ukur tujuan pembentukan atau perlindungan hukum Islam (maqasid asy-syari'ah) sebagai landasan yang digunakan untuk melihat tujuan strategi adapatasi yang dilakuakan Pedagang angkringan di sekitar Kawasan Jln. K.H. Ali Maksum Krapayak Bnatul Yogyakarta dalam mempertahankan eksistensi hidupnya.

\section{Teknik Pengumpulan data}

Teknik pengumpulan data yang penyusun pergunakan adalah

\section{Wawancara}

Wawancara adalah proses Tanya jawab dalam penelitian yang berlangsung secara lisan dalam mana dua orang atau lebih dengan bertatap muka, mendengarkan secara langsung informasi atau keterangan-keterangan. (Cholid Narkubo. 2007. 483). Dalam hal ini penulis melaksanakan wawancara dengan Pedagang angkringan di sekitar Kawasan Jln. K.H. Ali Maksum Krapayak Bnatul Yogyakarta mengenai strategi adaptasi dalam mempertahankan eksistensi hidupnya.

4Deskriptif-analitik berarti meneliti dengan cara menguraikan data yang penyusun peroleh guna menganalisis serta memecahkan permasalahan yang ada ke dalam bagian-bagian menurut metode yang konsisten untuk mencapai pengertian yang jelas serta pemahaman yang menyeluruh. Lihat dalam ( Winarno Surahmad.1990. 139). Dengan demikian penelitian deskriptik-analitik bertujuan menggambarkan secara tepat sifat-sifat suatu individu, keadaan, gejala atau kelompok tertentu, atau untuk menentukan penyebaran suatu gejala, atau untuk menentukan ada tidaknya hubungan antara suatu gejala dengan gejala lain dalam masyarakat. (Amiruddin dan Zaenal Asikin, 2004. 25).

5 Normatif; berpegang teguh pada norma, menurut norma atau kaidah yang berlaku. Maksud penelitian hukum yang bersifat normatif adalah mengkaji sistematika peraturan perundangundangan sehingga jelas faktor-faktor dominan yang mempengaruhi pembentukan hukum tersebut dan selanjutnya menelaah sinkronisasi suatu peraturan perundang-undangan tersebut dengan Hukum Islam.

Kurniati 188

JURNAL EKONOMI SYARIAH INDONESIA, Volume V, No.2 Desember 2015 
Sampling

Dalam melakukan wawancara, penyusun mengambil sumber data berdasarkan sample dari masing-masing jenis pedagang angkringan, yakni masing-masing dari jenis angkringan tradisional dan angkringan modern. ${ }^{6}$

\section{Observasi}

Observasi adalah alat penggunaan data yang dilakukan dengan cara mengamati dan mencatat secara sistemik gejala-gejala yang diselidiki.(Cholid. 2007.70). Dalam penelitian ini penulis menggunakan metode observasi non partisipan dimana peneliti tidak ikut terlibat langsung dalam penanganan masalah yang sedang diteliti. Peneliti dalam hal ini hanya mengamati strategi apa saja yang dilakukan strategi adapatasi yang dilakuakn Pedagang angkringan di sekitar Kawasan Jln. K.H. Ali Maksum Krapayak Bnatul Yogyakarta dalam mempertahankan eksistensi hidupnya.

\section{Dokumentasi}

Dokumentasi merupakan metode yang mana bertujuan untuk mencari data mengenai hal-hal atau variabel yang berupa catatan, transkip, buku, surat kabar, majalah, prasasti, notulen rapat, agenda dan lain sebagainya. (suharsimi. 1993. 202.) Dalam hal ini peneliti berupaya memperoleh data yang bersifat dokumentasi dari dokumen-dokumen yang ada sehingga dapat lebih mudah dalam menganalisis data.

\section{Metode Analisis Data}

Semua Data yang telah diperoleh kemudian diklasifikasikan secara sistematis, selanjutnya dilakukan analisis data. Adapun analisis data ini bertujuan untuk menyederhanakan data dalam bentuk yang lebih mudah dibaca dan diinterpretasikan(Masrisinga. 1989. 236). Analisa data yang digunakan adalah analisa data deskriptif kualitatif yaitu penyajian data dalam bentuk tulisan dan menerangkan sesuai data yang diperoleh dalam penelitian.

\section{PEMBAHASAN}

\section{Selayang Pandang Kampung Krapyak}

Desa panggungharjo termasuk dalam wilayah daerah kecamatan sewon yang memiliki luas wilayah 561Ha. Jarak antara kota kecamatan dengan ibu kota propinsi Yogyakarta $\pm 3 \mathrm{~km}$ dan dapat ditempuh \pm 15 menit dengan menggunakn kendaraan, ini menunjukkan bahwa transportasi yang tersedia sangat mudah, lancar serta terjangkau. Adpun luas tanah yang ada di desa Panggungharjo sebagian besar digunakan untuk bangunan permanen, seperti untuk bangunan sekolah, perkantoran, pos kamling dan lain lain. Luas tanah yang digunakan untuk bangunan permannen seluas $300 \mathrm{Ha}, 223 \mathrm{Ha}$ untuk tanah sawah, dan selebihnya sekitar 38 Ha di gunakan untuk lain lain.

Penduduk didesa Panggungharjo kecamatan sewon berjumlah sebanyak 23.436 jiwa sesuai dengan jumlah penduduk yang berkewarganegaraan Indonesia, terdiri drai penduduk yang berjenis kelamin laki-laki sebanyak

Strategi Adaptasi 11.907 jiwa, dan penduduk yang jenis kelamin perempuan sebanyak 11.529 jiwa. Sehingga penduduk Panggungharjo terbanyak adalah penduduk yang

6Dalam penelitian ini penyusun mengelompokkan usaha ankringan menjadi dua, yakni angkringan tradisional yang masih menyajikan daganganya di grobak dan angkringan modern yang telah dimodifikasi dengan berbagai fasilitas seperti Televisi, Hot Spot, dll.

JURNAL EKONOMI SYARIAH INDONESIA, Volume V, No.2 Desember 2015 
berjenis kelamin laki-laki. Adpun jumlah kepala keluarga yang ada sebanyak 7162 kepala keluarga.

Tabel 1. Banyaknya penduduk di kelurahan Panggungharjo berdasarkanjenis kelamin

\begin{tabular}{lll}
\hline \multicolumn{1}{c}{ Jenis Kelamin } & \multicolumn{1}{c}{ Jumlah } & \multicolumn{1}{c}{ Prosentase (\%) } \\
\hline Laki-Laki & 11.907 jiwa & $51 \%$ \\
Perempuan & 11.529 jiwa & $49 \%$ \\
\hline Jumlah & 23.436 jiwa & $100 \%$ \\
\hline
\end{tabular}

Sumber: data Demografi Kelurahan Panggunharjo 2002.

Adapun kondisi pendidikan kelurahan panggungharjo tergolong kurang baik, hal ini dapat kita lihat dari sebagian besar penduduknya yang hanya mengenyam pendidikan hanya sampai sekolah dasar saja.

Tabel 2. Tingkat Pendidikan penduduk di Kelurahan Panggungharjo

\begin{tabular}{cc}
\hline Lulusan Pendidikan & Jumlah \\
\hline SD & 1.044 \\
SLTP & 846 \\
SLTA & 549 \\
Akademi/Sarjana & 662 \\
\hline Jumlah & 3.101. \\
\hline
\end{tabular}

Sumber : Data monografi Kelurahan Panggungharjo.

Jika dilihat dari kehidupan sehari-harinya, penduduk desa Panggungharjo termasuk dalam golongan kelas menengah keatas (keluarga mampu), dan hanya sebagian kecilnya saja yang termasuk dalam golongan bawah (keluarga miskin). Dalam kesehariannya penduduk desa panggungharjo memiliki mata pencaharian beternak (unggas, kambing, domba) dan berdagang. Sehingga dari masing-masing mata pencaharian dapat diketahuipotensi pendapatan mereka. Adapun pengembangan usaha perdagangan mereka lakukan melalui sarana perekonomian yang ada seperti kios, toko, warung, dan swalayan. Lebih jelasnya dapat dilihat pada tabel berikut:

Tabel 3. Jenis mata pencaharian penduduk desa panggungharjo.

\begin{tabular}{lll}
\hline \multicolumn{1}{c}{ Mata Pencaharian } & Jumlah \\
\hline Pertanian & 253 \\
Peternakan & 2.606 \\
Perikanan/ nelayan & 60 \\
Industri Kecil & 1.117 \\
Industri Besar & 1.662 \\
Perdagangan / Jasa & 1.117 \\
\hline Jumlah & 7.875 \\
\hline
\end{tabular}

Sumber: Data Demografi Kelurahan Panggungharjo.

Tabel 4. Banyaknya Sarana Perekonomian

\begin{tabular}{cccc}
\hline Kios & Toko & Warung & Swalayan \\
\hline 10 & 75 & 89 & 5 \\
\hline
\end{tabular}

Sumber: Data Monografi Kelurahan Panggungharjo 
Jika dilihat dari kondisi perdagangan di desa Panggungharjo adalah adanya banyak pertokoan, kios, warung, dan swalayan yang menjual produknya untuk memenuhi kebutuhan masyarakat atau anak-anak kost yang berasal dari luar daerah.

Angkringan di sekitar Kawasan Jln. Ali Maksum terletak di Area Pondok Pesantren Krapyak yakni di Dusun Krapyak Kulon, Desa Panggung Harjo, Kecamatan Sewon Kabupaten Bantul, Propinsi Daerah Istimewa Yogyakarta. Bagian utara berbatasan dengan tapal batas antara kotamadya Yogyakarta dan Kabupaten Bantul.

Dusun Krapyak Kulon adalah salah satu Dusun yang cukup maju dibandingkan dengan Dusun-dusun lainnya yang ada di Desa Panggung Harjo kemajuan ini karena di dukung oleh beberapa faktor, salah satunya adalah letak geografis yang sangat dekat dengan pusat kota dan pusat-pusat pendidikan di Yogyakarta. Keadaan ini secara otomatis dapat mempengaruhi pola pikir masyarakat baik sosial, budaya, dan ekonominya. Mayoritas penduduk dusun Krapyak beragama Islam.

Secara geografis, jarak tempuh Dusun Krapyak Kulon dengan kantor desa Pangung Harjo $\pm 1,5 \mathrm{Km}$, dengan kota kecamatan $\pm 3,5 \mathrm{Km}$, dengan kota kabupaten $\pm 8 \mathrm{Km}$, dengan kota propinsi $\pm 3 \mathrm{Km}$.

Letak yang strategis ini memberikan kemudahan bagi para pendatang untuk menjangkau tempat-tempat umum serta memudahkan untuk mendapatkan informasi maupun kebutuhan sehari-hari. Hal ini telah memberikan kontribusi bagi para pendatang untuk menentukan pilihanya yakni kos atau mondok di Krapyak.

Krapyak pada umumnya, dan Krapyak kulon pada khususnya sangat diuntungkan dengan adanya pondok Pesantren Krapyak yang begitu banyak mendatangkan pendatang dari berbagi kota di Indonesia, bahkan jumlah seluruh santri berkisar hingga 5000 santri, belum ditambah para mahasiswa yang indekos didekat pondok pesantren. Hal ini dapat meningkatkan kondisi ekonomi masyarakat Krapayak. Maka ketika kita melewati wilayah pesantren dan khususnya pada penelitian ini jln. K.H. Ali Maksum kan terlihat kehidupan pelaku ekonomi yakni pedagang makanan, toko, jamu yang begitu ramai didatng para santri dan mahasiswa yang kos di dekat pondok pesantren.

\section{Potret Pedagang Angkringan di Kawasan Sekitar Jln. K.H. Ali Maksum Krapyak Panggungharjo.}

Dalam observasi yang telah saya lakukan serta serangkaian wawancara maka peneliti hanya mengambil dua sample dari beberapa pedagang angkringan yang ada di Krapayak. Yakni Kang Harjo sebagai perwakilan sample pedagang angkringan yang sudah dimodifikasi, dan Kang Sadimin sebagai perwakilan sample pedagang angkringan yang belum berubah dengan artian masih tradisional. Demikianlah hasil wawancara yang telah peneliti lakukan yang telah kami gubah dalam bahasa non verbal.

\section{Angkringan Modern Kang Harjo}

Kang harjo yang bernama lengkap Suharjo adalah seorang penjual Strategi makanan dengan angkringan, beragama Islam, lahir di Bayat Klaten tepatnya Adaptasi 40 tahun yang lalu. Pak Suharjo sudah menikah dan memiliki enam (6) putra. Pak harjo hanya menyelesaikan pendidikannya di bangku SMA. Saat ini 191 beliau bertempat tinggal di Krapyak Kulon bersama istri dan putra-putrinya. 
Migrasi dari desa Bayat Klaten (1989) langsung menuju Krapyak Yogyakarta dan langsung menekuni usaha sebagai pedagang angkringan. Sebelum menjadi pedagang angkringan keliling dengan grobak didorong beliau menjadi suplier angkringan. Diantaranya bahan baku untuk membuat berbagai makanan dan minuman, beras. Gula, jahe, sayuran, dab juga makanan kering seperi krupuk, kripik belut\& usus, nasi kucing,dll.

Namun karena dirasa lebih menguntungkan apabila dijual sendiri maka sambil tetap menjadi suplier makanan angkringan beliau menjual sendiri dengan cara mendorong angkringan di Krapyak dan sekitarnya. Usaha berdagang angkringan dengan mendorong grobak berkeliling beliau jalani kurang lebih 12 tahun.

Sejak menikah, kang harjo tidak berjualan berkeliling, akan tetapi memilih manggon (menetap) di jln. K.H. Ali Maksum Krapyak, dengan luas tempat hanya cukup untuk meletakkan gerobak angkringan dan bangku, kurang lebih seluas 2x2meter. (sepetak). Karena kegigihan beliau, mampu memperluas angkringanya seluas $275 \mathrm{~m} 2$ dengan tiga karyawan. Selain gigih kang harjo juga sangat pintar memutar modal yang terbatas. Berbeda dengan angkringan yang lain di angkringan kang harjo terdapat fasilitas televisi. Dan menjual berbagai macam lauk tambahan, seperti cumi, telur goreng, pecel dan yang paling berbeda adalah ketika diangkringan lain menjajakan nasi kucing, di angkringan kang harjo nasinya tersedia di tempat pemanas nasi, dan pelanggan yang ingin membeli makan dapat mengambilnya sepuas hati dengan harga yang terjangkau tergantung lauk pauk yang dipilihnya.

Pekerjaan pokok Kang Harjo pada saat ini adalah sebagai pedagang angkringan, sedangkan pekerjaan Bu Aminah istrinya adalah sebagai pengajar (guru) disebuah SMA di jogjakarta.

Adapun waktu pekerjaan pokok (buka) kang Harjo di angkringan ada 12 jam yaitu dari pukul 15.00 WIB s.d. pukul 03.00 WIB. Pada jam tersebut, kang Harjo akan dibantu oleh tiga karyawan, 2 laki-laki dan 1 perempuan. Sementara istrinya hanya membantu membuat makanan di rumah dan menjaga anak-anaknya yang berjumlah 6 .

Pekerjaan persiapan dimulai dari pagi hari, dengan waktu yang tidak tentu, dan yang membantu menyiapkan dagangan ini, adalah satu karyawannya yang tinggal di lokasi angkringan, membantu memasak air dan sayur-sayuran. Sedangkan lauk-lauk yang lain di masak di rumah.

Hari istirahat (tidak buka) untuk Pak Harjo sebagai pedagang angkringan tidak menentu, hanya pada hari-hari besar, seperti lebaran, dan kalau ada keperluan keluarga.

Dengan berjalnnya waktu angkringan Kang harjo semakin ramai dan diminati banyak orang.

Konsumen angkringan, meski sering dicap sebagai warung rendahan, pada kenyataannya terdiri dari berbagai kalangan. Mulai dari tukang becak, anak-anak perantauan, mahasiswa, budayawan dan seniman, karyawan hingga eksekutif kadang tak sungkan menghabiskan malam untuk menyantap makanan dan minum teh jahe di Angkringan.

Perilaku konsumen pun bermacam-macam di sana. Ada yang hanya membeli untuk dibawa pulang, ada pula yang membeli, makan sebentar lalu pulang, namun yang paling sering ditemui adalah membeli, ngobrol, membeli lagi, dan ngobrol lagi di warung angkringan bersama rekan maupun "rekan-rekan" baru yang ditemui dan di kenal di sana. Otomatis, di angkringan tidak ada pembedaan strata sosial, agama maupun ras. Mereka semua sama

\section{Kurniati}

JURNAL EKONOMI SYARIAH INDONESIA, Volume V, No.2 Desember 2015 
di keremangan lampu senthir, sebagai sosok anak manusia yang makan dan minum dari tangan penjual yang sama.

Pak Harjo selain menjadi pedagang angkringan juga memiliki pekerjaan sampingan yaitu sebagai suplier es dan Bahan baku untuk membuat berbagai makanan dan minuman yang akan saya buat mudah didapat, seperti beras. Gula, jahe, sayuran, dan lain ain.

Beliau melakukan kerjasama dengan penjual angkringan keliling, yakni kepada perantau-perantau yang belum mempunyai tempat tinggal untuk tinggal di rumahnya gratis, tetapi dengan syarat pedangang angkringna berjalan tersebut membeli bahan baku angkringan dari tempat beliau. Dan pedagang angkringan jalan tersebut sepakat daripada membayar uang sewa kos. Sehingga dengan demikian ada unsur timbal balik dari keduanya. Sampai saat ini terdapat tiga pedagang angkringan berjalan yang tinggakl di rumah kang harjo. Akan tetapi hubungan yang dilakukan bukan sebagai Juragan dan Karyawan, melainkan sebagai rekan kerja.

Selain tiga karyawan tersebut, juga masih terdapat satu lagi angkringan milik Kang Harjo yang diserahkan kepada karyawan yang telah lama membantu kang Harjo, angkringan Kang Agus yang letaknya kira-kira 5 meter dari angkringan Kang Harjo. Meskipun berdekatan keduanya masih memiliki pelanggan masing-masing, karena jenis menu yang di perdagangkan juga berbeda. Angkringan Kang Agus ini menggunkan sistem 15 hari dikelola oleh managemennya Kang Agus sendiri dan 15 Hari dikelola oleh Karyawan Kang Harjo yang lain dibawah manajemen Kang Harjo.

Sementara itu Kang Harjo Pindah di tempat yang lebih besar dan diberi nama angkringan kang harjo dengan uang sewa 15 juta per 5 tahun. Dan saat ini sudah memiliki 3 cabang, Kang Hajo 1 berada di Krapyak, Kang Harjo 2 berada di wijilan dan Kang Harjo 3 berada di sekitar wilayah UMY.

Dalam hal persiapan, menu yang bersifat "basah" seperti nasi, sayur, dan makanan pokok lainnya disiapkan / dimasak sendiri oleh keluarganya, sedangkan untuk menu yang bersifat "kering" seperti kerupuk, roti, kuekuean, dan kacang, merupakan titipan orang, dan ada juga yang dibeli di pasar.

Angkringan Kang Harjo unik sebab cara penyajian nasi sayurnya tidak dengan bungkusan-seperti angkringan pada umumnya tetapi dengan piring, dan nasinya akan tetap panas karena disimpan dalam termos nasi.

Karyawan yang membantu di angkringan Kang Harjo berjumlah 12 orang. Dengan jam bekerja dari jam 15.00-03.00 dengan honorarium Rp. 20.000 serta uang makan berfariasi Rp.10.000-Rp.15.000; dengan sistem kerja dan pembayarannya adalah setiap 15 hari kerja. Setelah 15 hari kerja setiap karyawan bergilir libur 5 hari dan memulai kerja lagi setelah 5 hari tersebut. Karyawan angkringan Kang Harjo semuanya tinggal ditempat tinggal mereka sendiri-sendiri, hanya ada satu karyawan yang tinggal di lokasi warung angkringan untuk membantu mempersiapkan dagangan.

Modal harian yang digunakan dalam usaha angkringan kang harjo tidak banyak berkisar Rp. 100.000-Rp.200.000 perhari yakni untuk membeli plastik, sedotan, dll. Karena makanan-makanan yang dijajakan sebagaian adalah titipan dari suplier.

Sistem pembayarannya adalah setiap 3 hari sekali ke suplier dan makanan yang tidak habis menjadi tanggung jawab supplier.

Angkringan Kang Harjo membutuhkan modal besar adalah ketika akan melebarkan usahanya dengan membuka cabang di Wijilan dan UMY, 
mengingat uang sewa yang cuku tinggi. Maka untuk menutupi kekurangan modalnya Kang Harjo meminjam di Bank Mandiri dan BPD unit UMKM. Karena usaha angkringannya maju maka tidak terlamapau sulit untuk mendaaptkan pinjaman, bahkan beberapa bank menawarkannya sendiri kerumah beliau.

Sampai sekarang belum terdapat kendala yang berarti bagi kang Harjo, mengingat usaha angkringan memang tidak membutuhkan modal yang besar. Hubungannya dengan suplier makanan pun terjalin dengan baik sebagai partner kerja yang saling membantu. Yakni Kang Harjo membantu memasrakan produk makanannya tesebut.

Omset penjualan setiap cabang pun beragam, untuk Kang Harjo I di Krapyak 1,5 juta- 2 juta per hari, Kang Harjo II yang berlokasi di Wijilan berkisar 1,8-2,5 juta perhari, sedangkan Kang Harjo III yang berlokasi di sekitar UMY merupakan cabang yang termuda baru berumur 2 tahun omsetnya berkisar 100-250 ribu. Sedangkan laba bersih yang diterima dari ketiga angkringan tersebut berkisar 300-400ribu perhari.

Biasanya angkringan paling ramai pada malam sabtu dan malam minggu, pada malam ini pengunjung dapat mencapai dua kali lipat konsumen pada hari biasanya.

\section{Angkringan Tradisional Kang Sadimin}

Kang Sadimin adalah seorang pedagang angkringan, beragama Islam, berasal dari Klaten, dan genap berumur 42 tahun Kang Sadimin sudah menikah dan dikaruniai 2 orang putra. Berbeda dengan Kang Harjo yang lulusan SMA, Kang Sadimin mengaku tidak mengenyam pendidikan sama sekali.

Kurang begitu jelas informasi yang saya peroleh ketika wawancara dengan Kang Sadimin, beliau terlihat malu-malu ketika ditanya tentang hal pribadinya. Tetapi yang pasti keluarganya tinggal di Jogjakarta.

Pekerjaan pokok Kang Sadimin adalah sebagai pedagang angkringan. Yang sudah ditekuninya \pm selama 20 tahun. Istrinya juga menemani beliau berjualan angkringan. Kadang juga dibantu oleh adik Iparnya. Angkringan Kang Sadimin mempunyai satu karyawan, yang bekerja dari jam 08.00-23.00 berbagi ship dengan istrinya dan adik iparnya. Jadi apabila dapat dikategorikan sebagai penjual angkringan pagi hari, karena dimulai pada pagi hari, tidak seperti angkringan yang lain yang baru buka pada sore hari dan tutup pada dini hari.

Pekerjaan persiapan dimulai dari pagi hari, dengan waktu yang tidak tentu, dan yang membantu menyiapkan dagangan ini adalah Istrinya, adik Iparnya dan adik kandungnya sendiri pria.

Hari istirahat (tidak buka) untuk Kang Sadimin hampir sama seperti Kang harjo, sebagai pedagang angkringan tidak menentu, hanya pada harihari besar, seperti lebaran, dan kalau ada keperluan keluarga.

Berbeda dari Kang Harjo, Kang Sadimin tidak mempunyai Usaha sampingan selain pedagang angkringan.

Dalam hal persiapan, menu yang bersifat "basah" seperti nasi, sayur, dan makanan pokok lainnya disiapkan / dimasak sendiri oleh keluarganya, sedangkan untuk menu yang bersifat "kering" seperti kerupuk, roti, kuekuean, dan kacang, merupakan titipan orang, dan ada juga yang dibeli di pasar. Biasanya menu yang berupa jajanan titipan uangnya diambil setiap hari. Dan jajanan yang tidak habis merupakan tanggung jawab suplier.

Kurniati

194

JURNAL EKONOMI SYARIAH INDONESIA, Volume V, No.2 Desember 2015 
Angkringan Kang Sadimin merupakan angkringan tradisional yang masih menyajikan menu tradisional seperti nasi kucing. Dan tempanya tentu saja tidak seluas angkringan kang Harjo. Akan tetapi angkringan ini juga tidak kalah larisnya dengan angkringan Kang Harjo. Satu bungkus Nasi Kucing harganya berkisar Rp700- Rp. 800.

Langganan tetap Kang Sadimin adalah Santri, mahasiswa luar kota baik dari sekitar krapyak maupun dari daerah lain, tukang becak, para karyawan konter dan usaha-usaha lain yang berjajar di sepanjang jalan K.H. Ali Maksum Krapyak. Sedangkan langganan tidak tetapnya -tapi cukup banyak, yaitu para pejalan pedestrian yang lewat di sana.

Status gerobak yang dipakai oleh Pak Sdaimin adalah milik sendiri, dan semuanya berjumlah satu buah.

Sebelum menjadi pedagang angkringan Kang Sadimin pernah mengundi Nasib ke Jakarta sebagai pedagang buah dingin. Hingga akhirnya pindah ke Jogjakarta menekuni Usaha angkringan. Lokasi yang untuk berjualan, merupakan lokasi sewaan dengan harga sewa 2 juta pertahun.

Pengeluaran rutin harian yang dikeluarkan berkisar Rp. 50.000- Rp. 100.000 per hari. Pendapatan kotor yang didapatkan perhari berkisar 1jt-1jt 250.ribu. Sedangkan Laba bersih yang diterima berkisar Rp.100.000-150.000 perhari.

Hal penting yang perlu dicatat adalah meskipun angkringan Kang Sdaimin masih bersifat tradisional tetapi pelanggannya juga banyak. Hal ini terlihat dari jumlah pembeli yang tidak pernah sepi.

Perbedaan pendapatan antara Kang Harjo dan Kang Sadimin adalah karena variasi menu yang ditawarkan. Menu yang ditawarkan di ankringan Kang Sadimin hanya menu utama angkringan tanpa dilengkapi menu-menu yang lain, seperti di angkringan kang Harjo hampir menyerupai rumah makan yang dikemas dalam jenis usaha angkringan.

\section{ANALISIS}

\section{Strategi Adaptasi yang dilakukan Pedagang Angkringan}

Berdagang Angkringan merupakan salah satu upaya yang ditempuh oleh Kang Harjo dan Kang Sadimin untuk mempertahankan hidupnya. Dalam kaitannya dengan upaya mempertahankan serta melangsungkan kehidupannya setiap manusia perlu melakukan adaptasi. Bagi manusia beradaptasi merupakan upaya untuk menghadapi lingkungan dan kondisi sosial yang berubah-ubah agar tetap bertahan.

Dari data yang diperoleh dapat diketahui bahwa salah satu strategiadaptasi yang dilakukan untuk mepertahankan eksistensi pedagang angkringan di Sekitar Krapyak sebagian dipengaruhi oleh faktor ekonomi. Mereka yang menjadi pedagang angkringan mayoritas berasal dari keluarga miskin, di mana mereka menjadi tulang punggung keluarga dalam hal perekonomian. Para pedagang angkringan dapat dikatakan kepepet menjadi pedagang angkringan pada awalnya karena merasa tidak mempunyai keahlian lain selain menjadi pedagang angkringan. Apabila ingin berdagang untuk jenis usaha yang lain, mereka harus menyediakan modal yang besar untuk itu.

Strategi Padahal sebagian pedagang angkringan tersebut berasal dari keluarga yang Adaptasi kurang mampu, sehingga mereka tidak berani mengambil resiko apabila terjadi kerugian. 
Hal ini akan berbeda ketika mereka memilih menjadi pedagang angkringan, meskipun keuntungan yang didapatkan tidak banyak, tetapi tidak membutuhkan modal yang besar. Selain itu berdagang angkringan juga terhindar dari risiko kerugian yang tinggi mengingat dalam mendapatkan produk yang akan dijual bekerjasama dengan suplier makanan, dgn berbagi keuntungan. Dan untuk makanan yang tidak habis dikembalikan kembali ke penyedia makanan. Kerjasama yang dijalin adalah pedagang angkringan sebagai distributor, dan penyedia yang memproduksi. Harga jual juga diserahkan sepenuhnya kepada pedagang angkringan, pihak penyedia tidak melakukan intervensi (campur tangan) dalam penetuan harga jual. Pihak penyedia hanya menentukan harga beli pedagang angkringan terhadap produknya.

Selain faktor ekonomi, masih ada faktor lain yang melatarbelakangi, faktor itu adalah faktor sosial. Sebagian dari responden yang pada awalnya menjadi pedagang angkringan untuk mempertahankan eksistensi hidupnya karena faktor ekonomi mengalami pergeseran ke faktor sosial, di mana rekan-rekan yang berasal dari daerah yang sama (Klaten) dan dengan pekerjaan yang sama, sehingga mereka tetap eksis bekerja sebagai pedagang angkringan. Mereka yang menjadi pedagang angkringan pada awalnya diajak oleh tetangganya, sehingga menjadi tertarik. Pergesaran dari faktor ekonomi ke faktor sosial dapat dilihat pada keterangan Kang Harjo bahwa hampir dari seluruh pedagang angkringan di Jogjakarta berasal dari Klaten. Ia menjelaskan bahwa pada awalnya ia bekerja sebagai buruh gendong karena kebutuhan untuk mencukupi ekonomi keluarga, namun setelah suami dan anak-anaknya meninggal hingga hanya tersisa tiga anak yang kini sudah dapat hidup mandiri membuat dirinya tetap bekerja sebagai penyalur makanan yang dijual di angkringan hanya untuk mencukupi kebutuhan pribadi dan untuk ditabung. Namun lama kelamaan tertarik untuk membuka angkringan sendiri. Begitu pula dengan Kang sadimin yang sama-sama dari Klaten, awalnya beliau menjadi penjual buah dingin kelilinh dan berpindah menjadi pedagang angkringan.

Mereka yang menjadi pedagang angkringan secara sosial tetap diterima dalam masyarakat sekitar tempat tinggalnya. Dari beberapa responden mereka mengakui tetap diterima oleh lingkungannya, tidak ada yang pernah dihina ataupun dikucilkan. Hal ini terjadi karena sebagian besar dari pedagang angkringan berasal dari daerah yang sama (bertetangga). Hal ini mengingat kebanyakan para pedagang angkringan dapat hidup dengan layak dan beberpa dari mereka bahkan ada yang sukses dan memiliki grobak angkringan lebih dari satu, seperti kasus Kang Harjo. Dalam hal ini Kang Sadimin meskipun lebih lama menekuni usaha ngkringan dari pada Kang Harjo, meskipun belum memiliki cabang, tetapi mengaku merasa kecukupan dengan keadaanya yang sekarang.

Upaya Pertahanan Diri dalam Dinamika dan Tantangan Perekonomian di Kawasan Krapyak oleh pedagang angkringan bermacama-macam:

Kang harjo melakukan upaya pertahanan diri dengan memodifikasi angkringannya dengan berbagai fasilitas tambahan seperti televisi, tempat yang luas, dan menu yang berfariasi, sehingga konsumen merasa nyaman dengan pelayanan yang memuaskan.

Lain halnya Kang Sadimin yang melakukan upaya pertahanan diri dengan memindah jam usaha, yang biasanya angkringan buka pada sorehingga dini hari, Kang sadimin memilih buka usaha pada pagi hingga

Kurniati

196

JURNAL EKONOMI SYARIAH INDONESIA, Volume V, No.2 Desember 2015 
malam hari, yakni dari jam 08.00-23.00. Kang sadimin juga lebih memilih mepekerjakan keluarga, yakni adiknya sendiri dan adik ipar nya serta istrinya untuk membnatunya berjualan angkringan dari pada mencari karyawan dari luar seperti Kang Harjo.

Kang Harjo dalam mencari modal tambahan untuk mengembangkan usahanya dengan meminjam di Bank, sedangkan Kang Sadimin dengan cara menabung, yakni menyisikan dari keuntungan setiap harinya untuk membayar uang sewa tempat.

\section{Strategi Adaptasi Pedagang Angkringan dalam Perspektif Etika Bisnis Islam}

Dari hasil pengamatan dan wawancara penulis dengan pedagang angkringan mengenai strategi adaptasi pedagang angkringan dalam mempertahankan eksistensi hidupnya, ditinjau dari etika bisnis Islam, tampaknya tidak terdapat faktor-faktor yang terlarang dalam menjalankan usahanya.

Apabila dilihat dari kehalalan produk yang diperjual belikan, maka makanan yang diperjual belikan di angkringan memenuhi syarat kehalalan. Sedangkan apabila dilihat dari aspek transaksi yang berlangsung, hal ini juga berlangsung sesuai dengan aspek syariah yakni kerelaan diantara keduanya (pedagang-pembeli) serta (pedagang-suplier), tidak ada unsur paksaan, semua berjalan sesuai dengan kekeluargaan.

Persaingan yang terjadi dengan strategi yang berbeda antara Kang Harjo dan Kang Sadimin juga masih dalam taraf yang wajar dan tidak melanggar etika bisnis islam.

Dimana dalam etika bisnis Islam dilarang adanya penipuan (tadlis), pemalsuan, ketidak jelasan (ghara), monopoli, pemaksaan, riba, mengurangi takaran dan timbangan, dan lain lain. Dalam praktek jual beli serta strategi yang dilakukan oleh keduanya tidak mengandung unsur-unsur tersebut.

\section{KESIMPULAN}

Kajian tentang strategi adaptasi dimaksudkan untuk mengungkap sistem pengetahuan dari sekelompok masyarakat atau komunitas yang diwujudkan dalam tingkah laku. Dalam kajian ini diperoleh pengetahuan pedagang angkringan yang digunakan untuk mengatasi masalah-masalah yang ditemui dalam kegiatan usahanya. Strategi produksi dan strategi penjualan serta strategi pelayanan yang dilakukan angkringan Kang Harjo untuk menjaga kelangsungan usaha dan memajukan usahanya. Pada pola-pola strategi tersebut di atas, tersirat perilaku moral yakni saling percaya antara suplier dan pedagang, Karyawan dan Juragan (kang Harjo) dan pedagang dengan Konsumen . begitu pula dengan perilaku rasional yakni untuk mendapatkan keuntungan yang lebih besar dengan menawarkan berbagai jenis makanan dan minuman yang berbeda dari angkringan tradisonal.

Kang Harjo dapat dijadikan percontohan pedagang angkringan yang sukses, dengan tiga cabang yang dimiliki, mengingat upaya beliau yang begitu gigih dari penjual angkringan dorong yang berjalan mendoronggrobak

Strategi angkringannya sampai mempunyai 12 karyawan dan mendidik karyawan Adaptasi menjadi pedagang mandiri. 


\section{DAFTAR PUSTAKA}

Nata, Abuddin. Metodologi Studi Islam, cet. ke-3.1999. Jakarta. PT Raja Grafindo Persada.

Abdurrahman, Asmuni. Qa'idah-Qa'idah Fiqih\{ (Qawa'idul Fiqh). 1976. Jakarta. Bulan Bintang.

Basyir, Ahmad Azhar. Asas-Asas Hukum Muamalah, edisi revisi. 2000. nYogyakarta. UII Press

Hasan, Fuad. dan Koentjaraningrat, Beberapa asas metodologi Ilmiah, dalam Metode-Metode penelitian Masyarakat. 1986. Jakarta. PT. Gramedia.

Surahmad, Winarno. 1990. Pengantar Penelitian Ilmiah, cet. ke-8. Jakarta: Tarsit.

Amiruddin dan Zaenal Asikin, Pengantar Metode Penelitian Hukum, cet. ke-1. 2004. Jakarta. PT Raja Grafindo Persada.

Narbuko, Cholid. \& Abu Achmadi. 2007. Metode Penelitian. Jakarta, PT RajaGrafindo Persada.

Arikunto, Suharsimi. 1993. Prosedur Penelitian Suatu Pendekatan Praktek. Jakarta: Rinika Cipta.

Rimbun, Masrisinga dan Sofyan Efendi (ed), 1989. Metode penelitian Survei. Jakarta: LP3ES

Syarifuddin, Amir. 2002. Meretas Kebekuan Ijtihad Isu-Isu Penting Hukum Islam Kontemporer di Indonesia, cet. Ke-1. Jakarta. Ciputat Pers.

Suparlan, Parsudi. 1984. Manusia Kebudayaan, dan Lingkungannya. Jakarta: Rajawali

Ahimsaputra, Heddy Shri. 1980. Penjual Sate ayam dari Madura di Yogyakarta; Studi tentang Perubahan Strategi Beradaptasi mereka. Skripsi S1 UGM, Yogyakarta.

Kurniati

198

JURNAL EKONOMI SYARIAH INDONESIA, Volume V, No.2 Desember 2015 